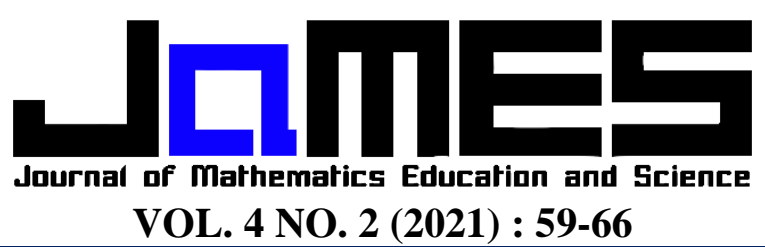

p-ISSN: 2621-1203 | https://doi.org/10.32665/james.v4i2.230

e-ISSN: 2621-1211

\title{
PENGELOMPOKAN PRODUKSI PERKEBUNAN MENURUT KABUPATEN/KOTA JAWA TENGAH TAHUN 2020 MENGGUNAKAN HIERARCHICAL CLUSTERING
}

\author{
Nur Mutmainnah Djafar ${ }^{1}$, Latifah Nur Wijayanti ${ }^{2}$, Ajeng Retno Elprilita ${ }^{3}$, Edy Widodo ${ }^{4}$ \\ Corresponding author : N. M. Djafar \\ Universitas Islam Indonesia, 18611078@ students.uii.ac.id ${ }^{1}$ \\ Universitas Islam Indonesia, 18611075@students.uii.ac.id² \\ Universitas Islam Indonesia, $18611077 @$ students.uii.ac.id ${ }^{3}$ \\ Universitas Islam Indonesia, edywidodo@uii.ac.id ${ }^{4}$ \\ Received : 10 September 2021, Revised : 13 Oktober 2021, Accepted : 24 Oktober 2021 \\ (C) Mathematics Education Unugiri 2021
}

\begin{abstract}
Indonesia is a country with arable land and empowered to do things; one of them is plantation. One of the provinces in Indonesia having a wealth of natural resources is Central Java. According to Dinas Penanaman Modal dan Pelayanan Terpadu Satu Pintu Provinsi Jawa Tengah, Central Java Province has great potential of the land. Based on BPS data, Central Java is in the seventh position in the results plantation production in 2020. Central Java Province also has the highest exported agriculture that won Abdi Tani Award in 2021. Researchers conducted using hierarchical clustering analysis method to know district/city group and productivity based on the results of plantation production. By the grouping results based on a coconut plantation, rubber tree, coffee, cocoa, sugar cane, tobacco, and pepper production, there are three clusters with profiling results are the first cluster has 30 districts/cities with high category plantation production, the second cluster has one district with middle category plantation production, and the third cluster has four districts/cities with low category plantation production.
\end{abstract}

Keywords: Clustering, Hierarchical Clustering, Plantation, Production

\begin{abstract}
Abstrak
Indonesia adalah negara yang memiliki tanah subur sehingga dapat diberdayakan untuk berbagai hal, salah satunya adalah perkebunan. Salah satu provinsi di Indonesia yang memiliki kekayaan sumber daya alam berupa tanah subur adalah Provinsi Jawa Tengah. Menurut Dinas Penanaman Modal dan Pelayanan Terpadu Satu Pintu Provinsi Jawa Tengah, Jawa Tengah memiliki potensi usaha dari hasil tanah yang sangat besar. Berdasarkan data BPS, Jawa Tengah berada di posisi ke-7 dalam hasil produksi perkebunan tahun 2020. Jawa Tengah juga merupakan provinsi dengan nilai ekspor pertanian tertinggi yang meraih penghargaan Abdi Bakti Tani 2021. Peneliti melakukan analisis dengan menggunakan metode hierarchical clustering, dengan tujuan untuk mengetahui kelompok-kelompok daerah serta produktivitasnya berdasarkan hasil produksi perkebunan. Dari hasil clustering dan profilisasi berdasarkan hasil produksi kelapa, karet, kopi, kakao, tebu, tembakau, dan lada diperoleh cluster 1 memiliki 30 kabupaten/kota dengan kategori hasil produksi perkebunan tinggi, cluster 2 memiliki 1 kabupaten dengan kategori hasil produksi perkebunan sedang, dan cluster 3 memiliki 4 kabupaten/kota dengan kategori hasil produksi perkebunan rendah.
\end{abstract}

Kata kunci: Clustering, Hierarchical Clustering, Perkebunan, Produksi

\section{Pendahuluan}

Indonesia adalah negara yang memiliki tanah subur sehingga dapat diberdayakan untuk berbagai hal, salah satunya adalah perkebunan. Mengutip dari laman BPS Indonesia, beberapa contoh dari bentuk 
produksi perkebunan dapat berupa kelapa, karet, kopi, kakao, tebu, tembakau, dan lada. Dari 34 provinsi di Indonesia, Jawa Tengah memiliki kekayaan alam berupa tanah subur. Berdasarkan data BPS, Jawa Tengah berada di posisi ke-7 dalam hasil produksi perkebunan tahun 2020.

Menurut Raharto [1], perkebunan merupakan bagian dari pertanian dalam arti yang lebih luas. Perkebunan dianggap berperan penting dalam memajukan perekonomian negara, seperti misalnya meningkatkan PDB (Produk Domestik Bruto), menciptakan devisa negara, dan sebagai persediaan pangan negara. Pertanian memiliki peranan penting dalam peningkatan ekonomi di Indonesia. Selain sebagai sumber pangan dan sumber devisa negara, pertanian juga berperan dalam penyerapan tenaga kerja [2].

Clustering perlu dilakukan supaya dapat diketahui cluster daerah berdasarkan hasil produksi perkebunan pada tahun 2020. Dari cluster yang telah diperoleh, peneliti dapat mengetahui produktivitas perkebunan dari masing-masing daerah.

Salah satu alat analisis statistik yang bisa digunakan untuk mengelompokkan obyek tertentu adalah hierarchical clustering. Menurut Supranto [3] analisis cluster adalah analisis untuk mengclusterkan elemen yang mirip sebagai objek penelitian cluster yang berbeda dan independen (tidak saling berhubungan). Analisis cluster merupakan suatu metode yang digunakan untuk melakukan pengelompokan $n$ objek berdasarkan $p$ variabel yang memiliki karakteristik relatif sama [4]. Terdapat dua metode pengclusteran, yaitu hierarchical dan nonhierarchical [5]. Peneliti menggunakan hierarchical clustering dalam penelitian ini. Adapun kelebihan dari metode hierarchical clustering yaitu dendrogram memberikan gambaran grafis dan dapat mendeteksi berbagai bentuk serta ukuran cluster. Sedangkan kekurangan dari metode tersebut yaitu kompleksitas yang tinggi serta proses perhitungan yang lambat. Untuk metode nonhierarchical clustering memiliki kekurangan diantaranya sensitive terhadap outlier, tidak mampu digunakan untuk cluster yang bervariasi, dan sensitif terhadap skala data.[6]

Hierarchical clustering adalah analisis yang pengclusteran datanya dilakukan dengan cara mengukur jarak kedekatan pada setiap obyek yang kemudian membentuk sebuah dendogram [7]. Tahapan untuk melakukan analisis clustering dimulai dengan melakukan analisis deskriptif, kemudian dilakukan pengujian asumsi multikolinearitas, lalu menentukan ukuran jarak yang akan digunakan, selanjutnya menentukan metode terbaik berdasarkan nilai korelasi cophenetic. Setelah memperoleh metode terbaik, kemudian dilakukan pembentukan dendrogram dan diakhiri dengan melakukan profilisasi cluster [8].

Beberapa penelitian mengenai analisis clustering telah dilakukan, diantaranya adalah clustering kabupaten/kota di Jawa Tengah berdasarkan produksi palawija yang dilakukan oleh Widiharih, Wilandari, \& Saputra [9]. Kemudian penelitian juga dilakukan oleh Bangun [10] yang melakukan penelitian tentang analisis cluster berdasarkan faktor produksi padi di Sumatera Utara, dan penelitian mengenai analisis cluster juga dilakukan oleh Mu'afa [11] berdasarkan jenis pertanian di Provinsi Jawa Tengah.

Sementara itu sudah banyak penelitian yang membahas mengenai analisis clustering pada produksi hasil perkebunan di Indonesia. Namun masih sedikit yang meneliti tentang clustering pada produksi perkebunan Provinsi Jawa Tengah, sementara Jawa Tengah merupakan provinsi dengan nilai ekspor pertanian tertinggi yang meraih penghargaan Abdi Bakti Tani 2021 [12]. Abdi Bakti Tani merupakan program Kementrian Pertanian yang memberi penghargaan terkait kinerja bidang pertanian untuk unit kerja pelayanan public [13].

Berdasarkan pemaparan sebelumnya, peneliti tertarik melakukan hierarchical clustering hasil produksi perkebunan Provinsi Jawa Tengah tahun 2020 dikarenakan potensi 
hasil usaha dari hasil tanah yang dimiliki oleh provinsi tersebut cukup besar. Dengan dilakukannya hierarchical clustering, peneliti dapat mengetahui kelompok-kelompok daerah berdasarkan produksi perkebunannya. Dari hasil clustering, diharapkan bisa digunakan sebagai acuan dalam penentuan kebijakankebijakan pemerintah daerah terkait peningkatan hasil produksi perkebunan.

\section{Metode Penelitian}

Peneliti menggunakan data sekunder yang bersumber dari website BPS Provinsi Jawa Tengah [14]. Terdapat tujuh variabel independen yang akan digunakan dalam penelitian yaitu banyaknya produksi kelapa, karet, kopi, kakao, tebu, tembakau, dan lada menurut kabupaten/kota di Jawa Tengah dengan satuan ton.

Berikut adalah tahapan-tahapan penelitian yang dilakukan:

a. Mulai

b. Analisis deskriptif untuk mendeskripsikan atau memberi gambaran terhadap objek yang diteliti.

c. Melakukan pengujian multikolinearitas untuk mengetahui antar variabel yang digunakan dalam penelitian saling berhubungan (berkorelasi) atau tidak. Jika tidak ada korelasi antar variabel, maka dilakukan perhitungan jarak dengan metode euclidean namun jika terdapat korelasi antar variabel maka dilakukan perhitungan jarak dengan metode mahalanobis.

d. Melakukan pengujian pada beberapa metode untuk mendapatkan metode terbaik dengan melihat nilai koefisien korelasi cophenetic yang paling besar.

e. Setelah mendapatkan hasil metode yang terbaik kemudian akan menghasilkan dendrogram yang sebelumnya dilakukan pemotongan dendrogram dengan jumlah tertentu berdasarkan kriteria banyak cluster yang diinginkan peneliti, dan menghasilkan cluster dengan metode terbaik yang meliputi jumlah anggota pada setiap cluster dan anggota pada masing-masing cluster. f. Langkah terakhir adalah dilakukan profilisasi pada masing-masing cluster untuk mengetahui karakteristik dari masingmasing cluster dengan cara mencari ratarata masing-masing variabel pada tiap cluster.

g. Selesai.

\section{Pembahasan}

\subsection{Analisis Deskriptif}

Peneliti melakukan analisis deskriptif untuk melihat gambaran umum dari hasil produksi perkebunan di Jawa Tengah tahun 2020.

Tabel 1 Statistika Deskriptif

\begin{tabular}{cccc}
\hline & Min & Maks & Rata-rata \\
\hline Kelapa & 0 & 31508,4000 & 4784,4000 \\
Karet & 0 & 3056,3900 & 117,9900 \\
Kopi & 0 & 10611,0500 & 691,0870 \\
Kakao & 0 & 403,2000 & 45,8700 \\
Tebu & 0 & 42552,9300 & 5235,4300 \\
Tembakau & 0 & 13365,3400 & 1587,1300 \\
Lada & 0 & 193,3500 & 16,3400 \\
\hline
\end{tabular}

Diperoleh gambaran umum bahwa daerah dengan hasil produksi kelapa paling banyak dengan nilai 31508,4000 yaitu Kabupaten Kebumen dan nilai minimum 0 menunjukkan daerah yang tidak memproduksi kelapa, diantaranya Kota Semarang, Kota Magelang, Kota Pekalongan, dan Kota Tegal. Kemudian hasil produksi karet paling banyak dengan nilai 3056,3900 yaitu Kabupaten Cilacap dan terdapat 16 daerah lain yang tidak memproduksi karet.

Selanjutnya hasil produksi kopi terbanyak yaitu Kabupaten Temanggung dengan nilai 10611,0500 dan terdapat 7 daerah lain yang tidak memproduksi kopi. Lalu daerah dengan produksi kakao paling banyak dengan nilai 403,2000 yaitu Kabupaten Wonogiri dan terdapat 13 daerah lain yang tidak memproduksi kakao. Hasil produksi tebu paling banyak yaitu Kabupaten Pati dengan nilai 42552,9300 dan terdapat 8 daerah lain yang tidak memproduksi tebu.

Kemudian Kabupaten Temanggung adalah daerah dengan produksi tembakau paling tinggi yaitu 13365,3400 dan terdapat 9 daerah lain yang tidak memproduksi tembakau. 
Kabupaten Purbalingga adalah daerah dengan produksi lada paling banyak dengan nilai 193,3500 dan terdapat 11 daerah lain yang tidak memproduksi lada.

\subsection{Asumsi Clustering}

Asumsi yang harus terpenuhi dalam hierarchical clustering adalah bebas dari multikolinearitas. Hal tersebut dilakukan untuk menentukan ukuran jarak yang sesuai pada penelitian ini. Jarak Mahalanobis digunakan jika terdeteksi ada multikolinearitas. Sedangkan untuk variabel-variabel yang tidak terdeteksi ada multikolinearitas, maka digunakan jarak Euclidean. Pengukuran kesamaan variabel satu dengan variabel lainnya yang digunakan dalam penelitian dapat dilihat dari koefisien korelasinya. [15]

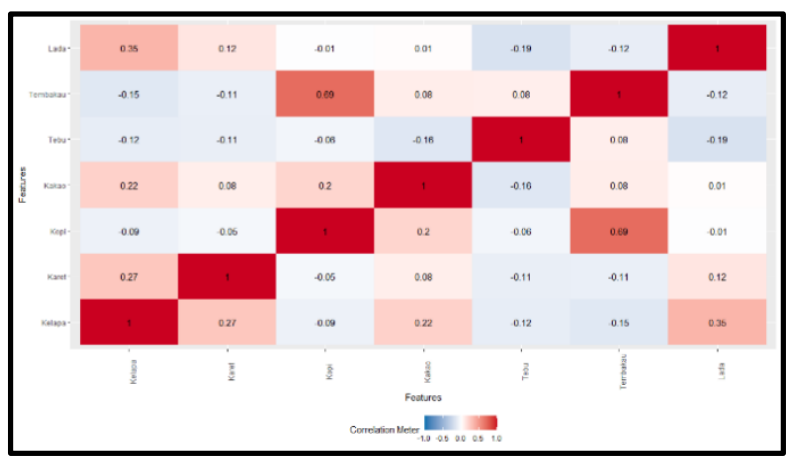

Gambar 1 Plot Korelasi Output Rstudio

Menurut Gujarati [16] dikatakan terjadi multikolinearitas jika terdapat koefisien korelasi sederhana yang mencapai atau melebihi 0,80. Berdasarkan gambar 3 variabel yang digunakan tidak memiliki nilai korelasi > 0,80, maka dalam penelitian ini digunakan jarak Euclidean. Jarak Euclidean digunakan untuk melihat tetangga terdekat dengan menghitung jarak antara 2 buah objek.[17] Berikut adalah beberapa hasil perhitungan jarak Euclidean:

Tabel 2 Perhitungan Jarak Euclidean

\begin{tabular}{cccc}
\hline & $\mathbf{1}$ & $\mathbf{2}$ & $\mathbf{3}$ \\
\hline 2 & 2900,0440 & & \\
3 & 4011,5675 & 3243,5841 & \\
4 & 4101,0938 & 3297,0431 & 990,5184 \\
5 & 17791,8267 & 16921,8983 & 20150,6213 \\
\hline
\end{tabular}

Berdasarkan Tabel 1, didapatkan bahwa jarak antara data pertama dengan data kedua sebesar 2900,0440, data pertama dengan data ketiga sebesar 4011,5675, begitupun seterusnya.

\subsection{Menentukan Metode Terbaik}

Terdapat lima metode cluster dan untuk penentuan metode terbaik peneliti menggunakan koefisien korelasi cophenetic. Semakin besar nilai korelasi cophenetic (mendekati satu), maka proses clustering menggunakan metode tersebut baik [18].

Tabel 3 Perbandingan Korelasi Cophenetic

\begin{tabular}{cc}
\hline Metode & Nilai Korelasi Cophenetic \\
\hline Average Linkage & 0,9042 \\
Complete Linkage & 0,8695 \\
Single Linkage & 0,8695 \\
Ward's & 0,8298 \\
Centroid & 0,9041 \\
\hline
\end{tabular}

Berdasarkan hasil koefisien korelasi cophenetic untuk kelima metode, diketahui bahwa nilai korelasi cophenetic pada metode average linkage memiliki nilai korelasi paling besar, maka metode tersebut adalah metode cluster terbaik untuk penelitian ini.

\subsection{Dendrogram dan Hasil Analisis Cluster}

Hasil cluster berdasarkan hasil produksi tanaman kelapa, karet, kopi, kakao, tebu, tembakau, dan lada dibagi menjadi tiga cluster dari proses pemotongan dendrogram. Cluster yang terbentuk diperoleh dari data yang memiliki jarak yang dekat dan karakteristik yang sama antar anggota pada satu cluster, sedangkan antara cluster satu dengan yang lain memiliki karakteristik yang berbeda. [19] Pembagian menjadi tiga cluster didasarkan pada penelitian terdahulu mengenai analisis cluster berdasarkan faktor produksi padi di Sumatera Utara yang dilakukan oleh Bangun pada tahun 2016 agar mendapatkan kategori tinggi, sedang, dan rendah. [20] 


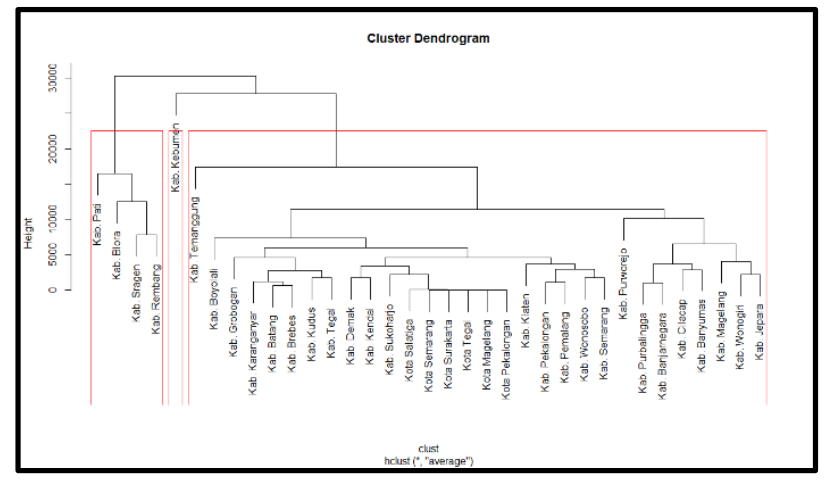

Gambar 2 Cluster Dendrogram

Terdapat tiga cluster yang terbentuk. Tiga cluster tersebut menunjukkan wilayah dengan tingkat produksi dari setiap jenis tanaman tersebut memiliki tingkatan rendah, sedang, atau tinggi berdasarkan hasil karakteristik clusternya nanti.

Hasil clustering dengan metode terbaik yaitu metode average linkage.

1) Jumlah anggota pada setiap cluster

Tabel 4 Jumlah Anggota Cluster

\begin{tabular}{cc}
\hline Cluster & Jumlah Anggota \\
\hline 1 & 30 \\
2 & 1 \\
3 & 4 \\
\hline
\end{tabular}

Berdasarkan tabel 2 didapatkan tiga hasil clustering dengan jumlah anggota pada cluster 1 sebanyak tiga puluh Kab/Kota, cluster 2 sebanyak satu Kabupaten, dan cluster ke 3 sebanyak empat Kab/Kota.

2) Anggota masing-masing cluster

Tabel 5 Anggota Cluster

\begin{tabular}{cl}
\hline Cluster & \multicolumn{1}{c}{ Anggota } \\
\hline & Kab. Banyumas, Kab. Cilacap, Kab. Kab. \\
& Banjarnegara, Purbalingga, Kab. Purworejo, \\
& Kab. Wonosobo, Kab. Wonogiri, Kab. \\
& Kendal, Kab. Batang, Kab. Magelang, Kab. \\
& Boyolali, Kab. Klaten, Kab. Sukoharjo, Kab. \\
1 & Karanganyar, Kab. Grobogan, Kab. Kudus, \\
& Kab. Jepara, Kab. Semarang, Kab. Demak, \\
& Kab. Pekalongan, Kab. Pemalang, Kab. Tegal, \\
& Kab. Brebes, Kota Magelang, Kota Surakarta, \\
& Kota Salatiga, Kota Semarang, Kota \\
& Pekalongan, Kota Tegal, Kab. Temanggung. \\
& Kab. Kebumen. \\
& Kab. Sragen, Kab. Blora, Kab. Rembang, \\
& Kab. Pati.
\end{tabular}

\subsection{Profilisasi}

Berdasarkan hasil clustering, kemudian dilakukan profilisasi untuk mengetahui karakteristik dari masing-masing cluster yang telah diperoleh. Profilisasi dilakukan dengan mencari nilai rata-rata hasil produksi perkebunan untuk masing-masing variabel pada setiap cluster sehingga diperoleh hasil sebagai berikut

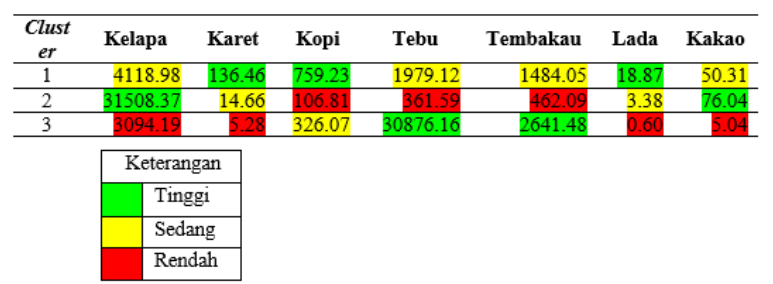

Gambar 3 Profilisasi Cluster

1) Cluster 1 adalah kelompok dengan hasil produksi perkebunan karet, kopi, dan lada tinggi, kemudian hasil produksi perkebunan kelapa, kakao, tebu, dan tembakau sedang. Oleh karena itu, secara keseluruhan cluster 1 merupakan cluster dengan hasil produksi perkebunan kategori tinggi dikarenakan lebih banyaknya kategori tinggi dari rata-rata keseluruhan.

2) Cluster 2 adalah kelompok dengan hasil produksi perkebunan kelapa dan kakao tinggi, lalu hasil produksi perkebunan karet dan lada sedang, kemudian hasil produksi perkebunan kopi, tebu, dan tembakau rendah. Oleh karena itu, secara keseluruhan cluster 2 merupakan cluster dengan hasil produksi perkebunan kategori sedang dikarenakan lebih banyaknya kategori sedang dan lebih sedikit kategori rendah dibandingkan dengan cluster 3 .

3) Cluster 3 adalah kelompok dengan hasil produksi perkebunan tebu dan tembakau tinggi, lalu hasil produksi perkebunan kopi sedang, kemudian hasil produksi perkebunan kelapa, karet, kakao, dan lada rendah. Oleh karena itu secara keseluruhan cluster 3 merupakan cluster dengan hasil produksi perkebunan kategori rendah dikarenakan lebih banyaknya kategori rendah dari rata-rata keseluruhan. 
Berdasarkan hasil clustering, peneliti selanjutnya membuat visualisasi hasil clustering sebagai berikut

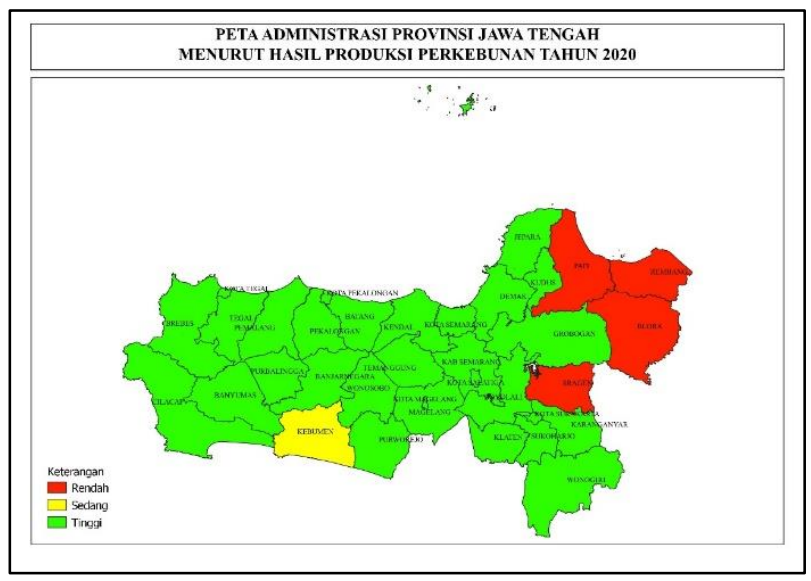

Gambar 4 Visualisasi Hasil Clustering

\section{Penutup}

Kesimpulan yang diperoleh dari penelitian ini diantaranya

1) Diperoleh gambaran umum bahwa daerah dengan hasil produksi kelapa paling banyak yaitu Kabupaten Kebumen dan terdapat beberapa daerah yang tidak meproduksi kelapa, diantaranya Kota Semarang, Kota Magelang, Kota Pekalongan, dan Kota Tegal. Kemudian hasil produksi karet paling banyak yaitu Kabupaten Cilacap dan terdapat 16 daerah lain yang tidak memproduksi karet. Selanjutnya hasil produksi kopi terbanyak yaitu Kabupaten Temanggung dan terdapat 7 daerah lain yang tidak memproduksi kopi. Kemudian daerah dengan produksi kakao paling banyak yaitu Kabupaten Wonogiri dan terdapat 13 daerah lain yang tidak memproduksi kakao. Selanjutnya daerah dengan produksi tebu paling banyak yaitu Kabupaten Pati dan terdapat 8 daerah lain yang tidak memproduksi tebu. Kemudian Kabupaten Temanggung adalah daerah dengan produksi tembakau paling tinggi dan terdapat 9 daerah lain yang tidak memproduksi tembakau. Selanjutnya Kabupaten Purbalingga adalah daerah dengan produksi lada paling banyak dan terdapat 11 daerah lain yang tidak memproduksi lada.

2) Berdasarkan hasil clustering, diperoleh tiga cluster dengan cluster pertama terdiri atas 30 kabupaten/kota di Jawa Tengah, cluster 2 terdiri atas 1 kabupaten/kota di Jawa Tengah, dan cluster 3 terdiri atas 4 kabupaten/kota di Jawa Tengah. Dari hasil profilisasi berdasarkan hasil produksi kelapa, karet, kopi, kakao, tebu, tembakau, dan lada, cluster 1 masuk dalam kategori hasil produksi perkebunan tinggi, cluster 2 masuk dalam kategori hasil produksi perkebunan sedang, dan cluster 3 masuk dalam kategori hasil produksi perkebunan rendah.

Saran yang dapat diberikan dari penelitian ini diantaranya

1) Saran untuk penelitian yang akan datang, supaya dapat melakukan penelitian dengan variabel yang lebih banyak dan metode lain yang berbeda dengan peneliti.

2) Saran untuk pemerintah atau instansi terkait, supaya dapat merencanakan program-program yang sekiranya dapat mengoptimalkan pemberdayaan sumber daya alam terutama perkebunan seperti misalnya penyuluhan dan pelatihan.

\section{Referensi}

[1] Raharto, Institutional Development Model Cocoa Farmers in East Java Province District Blitar, Journal Agriculture and Agricultural Science Procedia, Vol. 9, pp (2016) 95-102.

[2] Kusumaningrum, Septiana Indriani, Pemanfaatan Sektor Pertanian Sebagai Penunjang Pertumbuhan Perekonomian Indonesia, Jurnal Transaksi, Vol. 11 No.1 (2019).

[3] Supranto, J.. Analisis Multivariat Arti dan Interpretasi. Jakarta: Rineka Cipta. (2004)

[4] Sitepu, Robinson, Irmeilyana \& Berry Gultom, Analisis Cluster Terhadap Tingkat Pencemaran Udara Pada Sektor Industri di Sumatera Selatan, Jurnal Penelitian Sains, Vol. 14 No. 3A (2011).

[5] Prasetyo, E, Data Mining Mengolah Data Menjadi Informasi Menggunakan Matlab, Yogyakarta: Penerbit Andi (2014).

[6] Widyadhana, Dahayu, dkk, Perbandingan Analisis Klaster K-Means 
dan Average Linkage unuk Pengklasteran Kemiskinan di Provinsi Jawa Tengah, Jurnal PRISMA, Vol. 4 (2021).

[7] Nafisah, Q. \& Chandra, N.E., Analisis Cluster Average Linkage Berdasarkan Faktor-Faktor Kemiskinan di Provinsi Jawa Timur, Zeta - Math Journal, Vol. 3 No. 2 (2017).

[8] Rachmatin, Dewi, Aplikasi MetodeMetode Agglmerative dalam Analisis Klaster Pada Data Tingkat Polusi Udara, Jurnal Infinity, Vol. 3, No. 2 (2014).

[9] Widiharih, D.S., Wilandari, Y., \& Saputra, A.H., Analisis Cluster pada Kabupaten/Kota di Jawa Tengah Berdasarkan Produksi Palawija, Media Statistika, Vol. 5 No. 1, pp (2012) 1116.

[10] Bangun, R.H., Analisis Klaster Nonhierarki dalam Pengelompokan Kabupaten/Kota di Sumatera Utara Berdasarkan Faktor Produksi Padi, Agrica, Vol. 4 No. 1, pp (2016).

[11] Mu'afa, S.F., Undergraduate Thesis, Matematika, Fakultas Sains dan Teknologi, Universitas Islam Negeri Sunan Ampel Surabaya, Indonesia, 2019

[12] Portal Resmi Provinsi Jawa Tengah. 2021. Tertinggi Nilai Ekspor Pertanian, Jateng Raih Penghargaan Abdi Bakti Tani.

Tersedia: https://jatengprov.go.id/publik/ tertingginilai-ekspor-pertanian-jateng-raih penghargaan-abdi-bakti-tani/.

[13] Balai Penelitian Tanaman Aneka Kacang dan Umbi. 2020. Balitkabi Mengikuti Nominasi Abdi Bakti Tani 2020. Tersedia:

https://balitkabi.litbang.pertanian.go.id/b erita/balitkabi-mengikuti-nominasi-abdibak ti-tani-2020/

[14] Badan Pusat Statistik Provinsi Jawa
Tengah. 2021. Produksi Perkebunan Menurut Kabupaten/Kota dan Jenis Tanaman di Provinsi Jawa Tengah (ton) Tahun 2019-2020. Tersedia : https://jateng.

bps.go.id/indicator/54/997/1/produksi-

per kebunan-menurut-kabupaten-kotadan-jen is-tanaman-di-provinsi-jawatengah-ton-.h tml

[15] Everitt, B., \& Torsten, H, An Introduction to Applied Mutlivariate Analysis with R, New York: Springer (2011).

[16] Gujarati, D.. Basic Econometrics.The McGraw - Hill Companies. (1978)

[17] Pradana, Ifan Hari, Klasifikasi Citra Sidik Jari Berdasarkan Enam Tipe Pattern Menggunakan Metode Euclidean Distance, Dokumen Karya Ilmiah Universitas Dian Nuswantoro Semarang (2015).

[18] Alfina, Tahta, Budi Santosa \& Ali Ridho Barakbah, Analisa Perbandingan Metode Hierarchical Clustering, K-Means, dan Gabungan Keduanya dalam Cluster Data, Jurnal Teknik ITS, Vol. 1 (2012).

[19] Binus University. 2017. Clustering. Tersedia:

https://socs.binus.ac.id/2017/03/ 09/ clustering/.

[20] Bangun, R.H., Analisis Klaster Nonhierarki dalam Pengelompokan Kabupaten/Kota di Sumatera Utara Berdasarkan Faktor Produksi Padi, Agrica, Vol. 4 No. 1, pp (2016). 
http://journal.unugiri.ac.id/index.php/JaMES 